\title{
What is the impact of drug therapy with antiresorptive agents on the success of dental implants? a literature review
}

\author{
Qual é o impacto da terapia medicamentosa com agentes antirreabsortivos no sucesso dos \\ implantes dentários? uma revisão de literatura
}

¿Cuál es el impacto de la farmacoterapia con agentes antirresortivos en el éxito de los implantes dentales? una revisión de la literatura

Received: 09/26/2021 | Reviewed: 10/04/2021 | Accept: 10/07/2021| Published: 10/10/2021

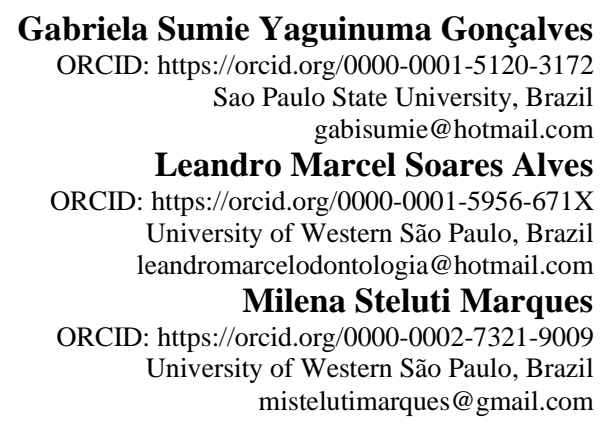

\begin{abstract}
Objective: To review the current literature and provide the latest information on anti-resorptive agent-induced osteonecrosis of the jaw (ARONJ), including our basic and clinical research findings, as well as discuss the risks of developing osteonecrosis in patients undergoing dental implant surgery in use of anti-resorptive drugs (ARDs). Methods: A literature review was performed using articles published in indexed journals based on Pubmed, Web of Science, Embase and Scopus databases. Results: Our results show that the placement of dental implants in patients treated with ARDs should be carefully evaluated, these patients are not free from complications and, therefore, the risk assessment should be done individually, as one of the most serious complications, although rare, is the ARONJ. Conclusion: Thus, all patients treated with this type of drug should be informed about the risk of implant loss or the possibility of osteonecrosis, being necessary to inform about the increased risk also patients who already have osteointegrated implants and will start therapy with bisphosphonates (BPT). And, in addition, establishing a relationship and collaboration between doctor, dentist and patient is essential for the good prognosis of these cases.

Keywords: Osteonecrosis; Antiresorptive drugs; Bisphosphonates; Dental implant; Success rate.
\end{abstract}

\begin{abstract}
Resumo
Objetivo: Revisar a literatura atual e fornecer as informações mais recentes sobre osteonecrose dos maxilares induzida por agente antirreabsortivo (ARONJ), incluindo nossos achados de pesquisa básica e clínica, bem como discutir os riscos do desenvolvimento de osteonecrose em pacientes submetidos à cirurgia de implante dentário em uso de drogas antirreabsortivas (ARDs). Métodos: Foi realizada uma revisão de literatura utilizando artigos publicados nos periódicos indexados com base em banco de dados Pubmed, Web of Science, Embase e Scopus. Resultados: Nossos resultados mostram que a colocação de implantes dentários em pacientes tratados com ARDs deve ser avaliada com cautela, esses pacientes não são isentos de complicações e, portanto, a avaliação do risco deve ser feita de forma individualizada, pois uma das complicações mais graves, embora raras, é a ARONJ. Conclusão: Desse modo, todos os pacientes tratados com este tipo de medicamento devem ser informados sobre o risco de perda do implante ou da possibilidade de osteonecrose, sendo necessário informar do risco aumentado também os pacientes que já têm implantes osteointegrados e vão iniciar a terapia com bisfosfonatos (BPT). E, além disso, estabelecer uma relação e colaboração entre médico, dentista e paciente é essencial para o bom prognóstico desses casos.
\end{abstract}

Palavras-chave: Osteonecrose; Drogas antirreabsortivas; Bifosfonatos; Implante dentário; Taxa de sucesso.

\section{Resumen}

Objetivo: Revisar la literatura actual y proporcionar la información más reciente sobre la osteonecrosis de la mandíbula inducida por agentes antirresortivos (ARONJ), incluidos los hallazgos de nuestra investigación básica y clínica, así como discutir los riesgos de desarrollar osteonecrosis en pacientes sometidos a cirugía de implantes 
dentales. en uso de fármacos antirresortivos (ERA). Métodos: Se realizó una revisión de la literatura utilizando artículos publicados en revistas indexadas basadas en las bases de datos Pubmed, Web of Science, Embase y Scopus. Resultados: Nuestros resultados muestran que la colocación de implantes dentales en pacientes tratados con ERA debe ser evaluada cuidadosamente, estos pacientes no están libres de complicaciones y, por lo tanto, la evaluación del riesgo debe realizarse de manera individual, como una de las complicaciones más graves, aunque poco frecuente. , es el ARONJ. Conclusión: Así, todos los pacientes tratados con este tipo de fármacos deben ser informados sobre el riesgo de pérdida del implante o la posibilidad de osteonecrosis, y es necesario informar sobre el aumento del riesgo también a los pacientes que ya tienen implantes osteointegrados e iniciarán terapia con bifosfonatos. (BPT). Y, además, establecer una relación y colaboración entre médico, odontólogo y paciente es fundamental para el buen pronóstico de estos casos.

Palabras clave: Osteonecrosis; Fármacos antirresortivos; Bisfosfonatos; Implante dental; Tasa de éxito.

\section{Introduction}

The most commonly used therapeutic resource for the treatment of osteoporosis involves the use of anti-resorptive drugs (ARDs) (Kunchur et al., 2009), which have the function of decreasing abnormal bone remodeling and/or increasing bone resorption (Ata-Ali et al., 2016). Despite differences in their mechanisms of action, these drugs, in general, inhibit the differentiation and normal function of osteoclasts, cells responsible for bone resorption, and/or increase their apoptosis (Rodan et al., 2002; Baron et al., 2011; Stavropoulos et al., 2018).

A growing number of reports have demonstrated an association between the use of ARDs (such as bisphosphonates (BPs), human monoclonal antibody against nuclear binding factor kappa B (RANK-L), denosumab, and cathepsin K inhibitors) and induced jaw osteonecrosis by anti-resorptive agent (ARONJ) (Stockmann et al., 2013; Guazzo et al., 2017).

More specifically, one of the most serious, although not as frequent, complications of ARDs therapy is bisphosphonate-related osteonecrosis of the jaws (BRONJ) (Ata-Ali et al., 2016), this condition, already recognized for more than a decade in relation to BPs, described for the first time by Marx, in 2003 (Marx et al., 2003), it is characterized by exposed and unhealed necrotic bone caused by current or previous treatment with anti-resorptive or anti-angiogenic agents (Ruggiero et al., 2014), which can be probed through an intraoral or extraoral fistula in the maxillofacial region and which persists for more than 8 weeks (Stavropoulos et al., 2018).

The lesions of this pathology are located in the bone matrix of the jaws, with a higher prevalence in the mandible compared to the maxilla (ratio 2:1) (Ruggiero et al., 2009), this fact can be justified due to the great vascularization, high rate of bone turnover, high risk of surgical trauma and local infections in the mandible (Vescovi et al., 2012). In addition, BPs had a strong affinity with hydroxyapatite, and $80 \%$ of the medications administered accumulated in the bones (Ikebe et al., 2013) and were released over time (varying from months to years) (Guazzo et al., 2017). As BPs have a long half-life due to their irreversible binding to bone, patients maintain their risk profile even after drug cessation; this property also explains the complications in which the cessation of bone resorption leads to interruption of bone renewal (Rawal et al., 2020).

As BPs significantly reduce bone turnover, it is not surprising that a patient undergoing this drug therapy may have a problem with the osseointegration of the dental implant (Goss et al., 2010). The American Dental Association warns that the placement of dental implants involves an increased risk of osteonecrosis in patients who are receiving oral treatment with BPs. Corroborating these findings, some authors (Jacobsen et al., 2013; López-Cedrún et al., 2013; Tam et al., 2014) have reported the appearance of osteonecrosis in patients undergoing dental implant placement. And, according to the American Association of Oral and Maxillofacial Surgeons, the frequency of osteonecrosis of the jaws in patients receiving intravenous BPs is 0.8$12 \%$ and the incidence is estimated at 0.7 per 100,000 person-years of exposure (Goss et al., 2010).

Some authors have reported a $99 \%$ success rate in dental implants in patients treated with oral BPs (Jeffcoat et al., 2006; Fugazzotto et al., 2007; Grant et al., 2008). However, other studies (Kasai et al., 2009; Yip et al., 2012) have reported a relationship between the use of BPs and dental implant failure. 
Several systemic and local risk factors have been correlated with the high frequency of development of this pathology (Vescovi et al., 2012). Exposure time/duration of therapy, drug potency and form of administration were considered risk factors related to the drug (Ruggiero et al., 2009; Guazzo et al., 2017). In addition, systemic diseases, consumption of other medications, smoking, alcohol consumption, age and race also exerted a great influence on BRONJ (Gelazius et al., 2018).

Bone trauma caused by the installation of osseointegrated implants is a predisposing factor for the disease. Therefore, its indication must be carefully evaluated and, if this treatment is chosen, preventive measures must be adopted, such as discontinuing the use of BPs, antibiotic prophylaxis prior to surgery and adequate prosthetic rehabilitation (Ferreira et al., 2020).

Thus, as a considerable number of patients seen in a dental clinic suffer from osteoporosis, most of them have received and/or are receiving treatment with ARDs, therefore, it is important to consider possible side effects; mainly for dentoalveolar procedures, including dental implants and their adjuvant treatments, which can be affected by drugs that interfere with the bone mechanism (Stavropoulos et al., 2018).

Therefore, the aim of this study was to review the current literature and provide the latest information on ARONJ, including our basic and clinical research findings, as well as to discuss the risks of developing osteonecrosis in patients undergoing dental implant surgery using ARDs.

\subsection{Clinical implications}

The relationship of ARDs with osteonecrosis is extremely relevant for professional practice, since, in any area in which the dental surgeon works, he/she must necessarily carry out a good anamnesis and clinical examination, in order to reach a correct diagnosis, as well as to know the conduct that should be used for the treatment of each phase of this disease.

\section{Methodology}

A literature review was performed using articles published in indexed journals based on Pubmed, Web of Science, Embase and Scopus databases. The selection of the articles was carried out by two independent reviewers previously calibrated (G.S.Y.G. and L.M.S.A.) and all discrepancies about the searches carried out in the databases were analyzed by a third reviewer (M.S.M.), through a consensus meeting. The authors conducted an electronic search on PubMed / MEDLINE, Web of Science, Embase and Scopus databases for articles published since September 2011 until September 2021 according to the eligibility criteria, using the following search term "Osteonecrosis; Antiresorptive drugs; Bisphosphonates; Dental implant; Sucess rate". The search strategy was as follows: "osteonecrosis" AND "antiresorptive drugs" OR "bisphosphonates" AND "dental implant" OR "sucess rate". Inclusion criteria were: (I1) randomized controlled clinical trials (RCTs), (I2) prospective studies, (I3) retrospective studies, (I4) in vivo clinical studies, (I5) articles with less than 10 years of publication, (I6) studies published in english language. The exclusion criteria were: (E1) in vitro studies, (E2) animal studies, (E3) with incomplete data that did not allow the collection of information. Following the protocol described by Estrela (Estrela, 2018).

The initial search resulted in a total of 571 articles. After eliminating those that did not refer to the topic, were duplicated or did not meet the inclusion/exclusion criteria, a full reading of the articles was made evaluating their methodological quality, obtaining twelve studies. Details on the search strategy are presented in the flowchart (shown in Figure $1)$. 
Figure 1. Study design (flowchart).

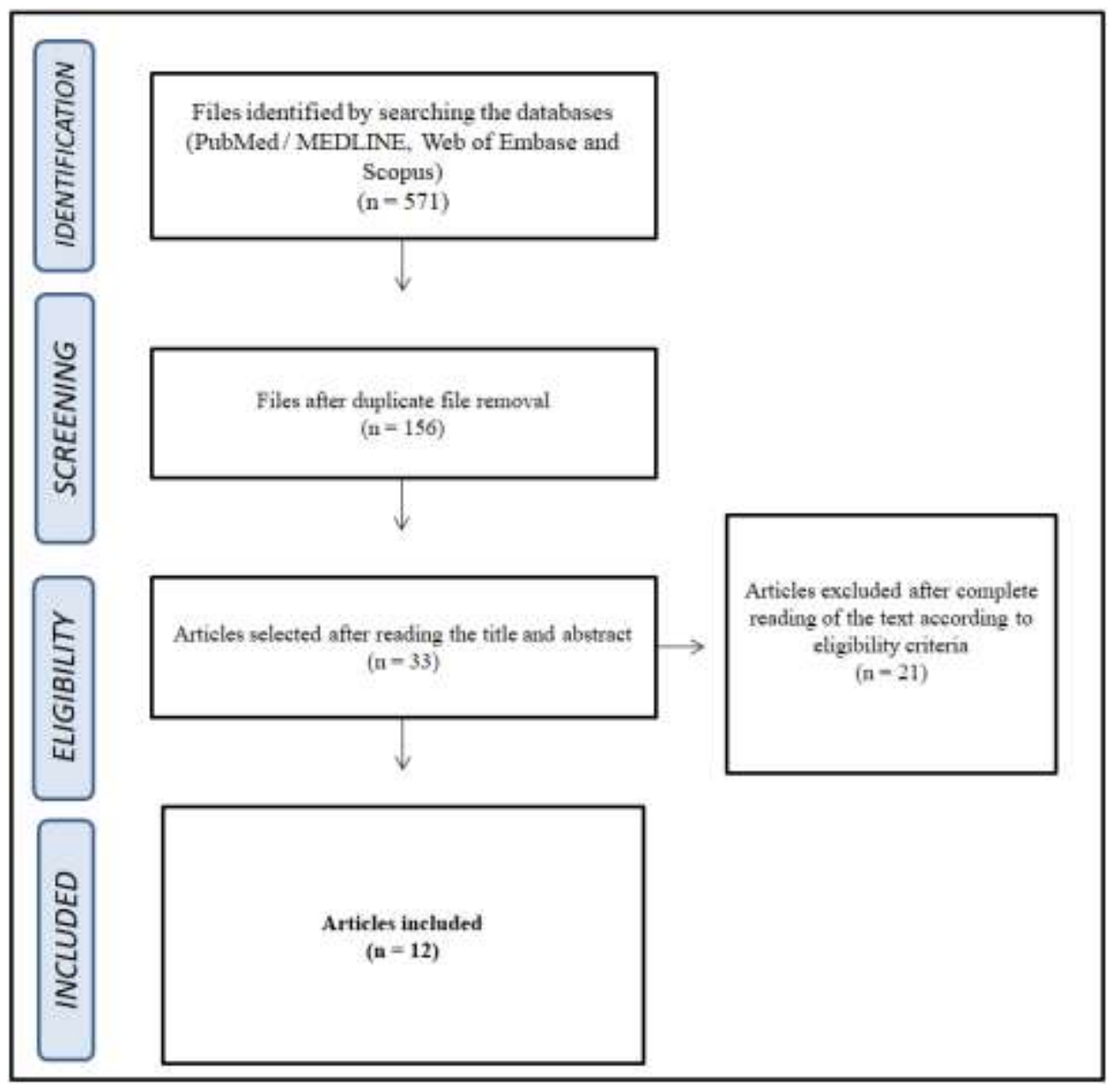

Source: Authors.

Regarding description of the studies, among these twelve articles, the authors compared the author, year, country, sex of patients and conditions they studied, these covered from medication-related osteonecrosis of the jaws, BRONJ and ARONJ until implant presence-triggered osteonecrosis (IPTO) and implant surgery-triggered osteonecrosis (ISTO) (Table 1). 
Table 1. General data on the selected studies.

\begin{tabular}{|c|c|c|c|c|}
\hline \multicolumn{5}{|c|}{ Research corpus } \\
\hline Author & Year & Country & Sex & Condition studied \\
\hline Vescovi et al. & 2012 & Italy & $\mathrm{F} / \mathrm{M}$ & Medication-related osteonecrosis of the jaws \\
\hline Giovannacci et al. & 2016 & Italy & F/M & Medication-related osteonecrosis of the jaws \\
\hline Mücke et al. & 2016 & Germany & F/M & Medication-related osteonecrosis of the jaws \\
\hline Ghidini et al. & 2017 & Italy & $\mathrm{F} / \mathrm{M}$ & BRONJ and medication-related osteonecrosis of the jaws \\
\hline Guazzo et al. & 2017 & Italy & $\mathrm{F} / \mathrm{M}$ & Osteonecrosis of the jaw \\
\hline Stavropoulos et al. & 2018 & Sweden & F/M & Medication-related osteonecrosis of the jaws \\
\hline Granate-Marques et al. & 2019 & Spain & $\mathrm{F} / \mathrm{M}$ & $\begin{array}{l}\text { Treatment with bisphosphonates other anti-resorptive } \\
\text { and antiangiogenic agents influences the success of } \\
\text { regenerative and / or implant treatments. }\end{array}$ \\
\hline Shibahara et al. & 2019 & Japan & $\mathrm{F} / \mathrm{M}$ & BRONJ and ARONJ \\
\hline Escobedo et al. & 2020 & Spain & $\mathrm{F} / \mathrm{M}$ & $\begin{array}{l}\text { Implant presence-triggered osteonecrosis (IPTO) and } \\
\text { implant surgery-triggered osteonecrosis (ISTO) }\end{array}$ \\
\hline Ferreira et al. & 2020 & Brazil & $\mathrm{F} / \mathrm{M}$ & $\begin{array}{l}\text { Risks of osteonecrosis in patients undergoing dental } \\
\text { implant surgery who use BPs }\end{array}$ \\
\hline Nisi et al. & 2020 & Italy & $\mathrm{F} / \mathrm{M}$ & Medication-related osteonecrosis of the jaws \\
\hline Pichardo et al. & 2020 & Netherlands & F/M & Medication-related osteonecrosis of the jaws \\
\hline
\end{tabular}

\section{Literature Review}

In the study by Shibahara et al. (2019) (Shibahara et al., 2019), the authors explained that BPs have been used as antiresorptive agents to treat patients with osteoporosis or metastatic bone cancer, each of which is characterized by bone loss due to increased bone resorption. bone malignancies, active Paget's disease of the bone, severe osteogenesis imperfecta and fibrous dysplasia, among others. In this sense, osteonecrosis of the jaw (ONJ), a possible side effect of this drug treatment, is associated with severe pain and deterioration in quality of life. The authors also pointed out that the maxillary bone is more susceptible to infections compared to bones from other parts of the body, due to its unique anatomical and physiological characteristics; for example, the mandible has a high rate of remodeling (it undergoes constant stimulation by the teeth during chewing) (Vescovi et al., 2012; Shibahara et al., 2019).

In the review by Mucke et al. (2016), the authors found that for patients with malignant disease taking bisphosphonates and denosumab, the incidence of BRONJ is up to $15 \%$ compared to $0.01 \%$ in patients with osteoporosis. The clinical presentation of BRONJ ranges from asymptomatic bone exposure in $94 \%$ of patients to severe cases of mandibular fractures in a minority of $4.5 \%$ (Mücke et al., 2016).

Nisi et al. (2020), in their study sample, found that patients were almost equally distributed in terms of underlying diseases in patients with osteoporosis and cancer patients. All BRONJ lesions were symptomatic and bone exposure was detected in six patients. A total of 40 implants were evaluated, with BRONJ being present in about 29 implants. Twelve patients were diagnosed with Stage III BRONJ and three patients with Stage II BRONJ. Surgical treatment led to complete healing in $86.7 \%$ of cases, with $100 \%$ success for maxillary BRONJ. The authors also concluded that surgical treatment appears to have a positive impact on BRONJ treatment in cases of peri-implant involvement. However, they reached a consensus that monitoring and prevention are essential in patients undergoing pharmacological treatment with antiresorptives/antiangiogenics, as peri-implant BRONJ can also develop in the absence of specific traumatic events (Nisi et al., 2020). Ghidini et al. (2017) agree that when BRONJ occurs, laser surgical treatment with Er:YAG seems to represent the 
option with the highest percentage of success for these cases; and, for patients with contraindications to surgery, low-intensity laser therapy (LLLT) helps to improve medical therapy outcomes (Ghidini et al., 2017).

Pichardo et al. (2020), in their results, showed an increased risk of developing BRONJ in patients with dental implants and considered that both peri-implantitis around previously placed implants and the insertion of dental implants are risk factors. Therefore, prevention of peri-implantitis and care when inserting dental implants in patients taking antiresorptive drugs are important. They also state that prevention strategies are the elimination of potential risk factors that lead to invasive dental procedures and the maintenance of good oral hygiene before administering anti-resorptive agents. The management of BRONJ depends on the underlying disease, the extent of necrosis, and the presence of contributing therapy. Conservative therapies include topical anti-infective rinses and systemic antibiotic therapy. The most important part of surgical therapy is to remove the exposed and necrotic bone and there are several options for closing the defect, from local tissue flaps to microvascular free flap procedures (Pichardo et al., 2020).

Giovannacci et al. (2016) analyzed fifteen patients with peri-implant bone osteonecrosis who were selected from a group of 250 patients (6\%). Patients were divided into two groups according to temporal relationship. Group 1 (G1) - necrosis immediately after implant placement (2 to 10 months) and defined as BRONJ triggered by implant surgery and Group 2 distant necrosis (1 to 15 years) from implant placement and defined as BRONJ triggered by the presence of an implant. In this study, epidemiological and pharmacological variables were recorded, as well as specific data on osteonecrosis and dental implants. G1 included six patients, five (83.4\%) treated with oral BPs for osteoporosis and 1 (16.6\%) with intravenous BPs for breast cancer. The mean duration of BP therapy (BPT) was 83.7 months. G2 included nine patients, eight (88.89\%) treated with intravenous BPs for malignant disease and $1(11.11 \%)$ with oral BPs for osteoporosis. The data confirm that not only the surgical insertion of dental implants is a potential risk factor for the development of osteonecrosis, but also the presence of the implant in the bone may be associated with this disease. Therefore, this study corroborates the findings of Pichardo et al., being necessary to inform the increased risk for BRONJ also in patients who already have osseointegrated implants and are going to start BPT. The risk is lower for patients who receive oral BPs, but exists and appears to be higher if the implant is located in posterior areas, if the duration of the BPT is greater than 3 years and if the patient is using corticosteroids (Giovannacci et al., 2016).

Escobedo et al. (2020) evaluated that the use of anti-resorptives causes osteonecrosis in patients with implants undergoing functional loads, this may be for patients in which the implants were placed before receiving the anti-resorptive, therefore, the loading period of these implants can be long; and this occurs at a higher frequency than that observed after implant placement surgery (Escobedo et al., 2020).

On the other hand, Stavropoulos et al. (2018) showed that the ingestion of oral BP in low doses for the treatment of osteoporosis, in general, does not compromise implant therapy, that is, patients using ARDs do not lose more implants nor have more complications/failures related to the implant compared to patients with implants without ingestion of BPs. However, there is almost no information available on the possible effect of implant therapy with high-dose BPs or other widely used ARDs (eg, denosumab), or on the success or safety of bone grafting procedures. Patients taking high-dose ARDs for the treatment of malignancies, patients with oral BPs for a long period of time, and patients with comorbidities should be considered high-risk patients for BRONJ (Stavropoulos et al., 2018).

Guazzo et al. (2017), in their systematic review, found no well-established evidence to support the safe use of BPs or other antiresorptive agents before, during, or after dentoalveolar surgery; in addition, the real risk of developing ONJ is still unknown, but it corresponds to a side effect that must be considered in the treatment (Guazzo et al., 2017).

In the systematic review by Granate-Marques et al. (2019), the authors also concluded that the literature on the subject is still scarce, requiring randomized clinical trials with long-term follow-up to establish protocols related to rehabilitation with 
implants in patients undergoing antiresorptive treatment. The risk of developing osteonecrosis associated with regeneration/placement of implants in patients with benign bone diseases is low, but exists and should not be underestimated (Granate-Marques et al., 2019), data that corroborate the study by Giovannacci et al. (Giovannacci et al., 2016).

Ferreira et al. (2020) agree that BPs promote a clear risk of developing osteonecrosis in the jaw. The duration of therapy, the type and method of administration of BPs are factors directly related to the appearance of this pathology. Bone trauma caused by the installation of osseointegrated implants is a predisposing factor for the disease, in addition to dental infection, poor oral hygiene and other bone-invasive dental treatments, such as tooth extractions. Therefore, its indication must be carefully evaluated and, if this treatment is chosen, preventive measures must be taken, such as discontinuing the use of BPs by the physician, antibiotic prophylaxis prior to surgery and adequate prosthetic rehabilitation (Ferreira et al., 2020).

\section{Conclusion}

Our results show that the placement of dental implants in patients treated with ARDs should be carefully evaluated, these patients are not free from complications and therefore the risk assessment should be done individually, as one of the most serious complications, although rare, is ARONJ. Thus, all patients treated with this type of drug must be informed about the risk of implant loss or the possibility of osteonecrosis, and it is necessary to inform patients who already have osteointegrated implants and are going to start a BPT of the increased risk. Furthermore, establishing a relationship and collaboration between physician, dentist and patient is essential for the good prognosis of these cases.

The range of potential sources of bias in the available studies limits the meaningful interpretation of the results. The lack of data from the results of randomized clinical trials makes it difficult to evaluate this treatment approach. Therefore, this review presents limitations that deserve to be overcome.

Based on the results of this study, in order to overcome these limitations, the need for further research such as randomized clinical trials with a large sample of long-term follow-up is suggested to better determine the impact of drug therapy with antiresorptive agents on success of dental implants and contribute positively to the current literature and to the improvement of clinical practice.

\section{References}

Advisory Task Force on Bisphosphonate-Related Ostenonecrosis of the Jaws, American Association of Oral and Maxillofacial Surgeons (2007). American Association of Oral and Maxillofacial Surgeons position paper on bisphosphonate-related osteonecrosis of the jaws. Journal of oral and maxillofacial surgery : official journal of the American Association of Oral and Maxillofacial Surgeons, 65(3), 369-376. https://doi.org/10.1016/j.joms.2006.11.003

American Dental Association Council on Scientific Affairs (2006). Dental management of patients receiving oral bisphosphonate therapy: expert panel recommendations. Journal of the American Dental Association (1939), 137(8), 1144-1150. https://doi.org/10.14219/jada.archive.2006.0355

Ata-Ali, J., Ata-Ali, F., Peñarrocha-Oltra, D., \& Galindo-Moreno, P. (2016). What is the impact of bisphosphonate therapy upon dental implant survival? A systematic review and meta-analysis. Clinical oral implants research, 27(2), e38-e46. https://doi.org/10.1111/clr.12526

Baron, R., Ferrari, S., \& Russell, R. G. (2011). Denosumab and bisphosphonates: different mechanisms of action and effects. Bone, 48(4), 677-692. https://doi.org/10.1016/j.bone.2010.11.020

Escobedo, M. F., Cobo, J. L., Junquera, S., Milla, J., Olay, S., \& Junquera, L. M. (2020). Medication-related osteonecrosis of the jaw. Implant presencetriggered osteonecrosis: Case series and literature review. Journal of stomatology, oral and maxillofacial surgery, 121(1), 40-48. https://doi.org/10.1016/j.jormas.2019.04.012

Estrela, C. (2018). Metodologia Científica: Ciência, Ensino, Pesquisa (3a ed.). Editora Artes Médicas.

Ferreira, G. Z., Bachesk, A. B., Bachesk, A. B., Farah, G. J., Filho, L. I., Dos Santos Silva, R., Poluha, R. L., Danieletto-Zanna, C. F., \& Gonçales, E. S. (2020). Oral Rehabilitation With Dental Implants and the Importance of a Preventive Evaluation for Osteonecrosis of the Jaws Associated With Medications. The Journal of oral implantology, 46(4), 431-437. https://doi.org/10.1563/aaid-joi-D-19-00275

Fugazzotto, P. A., Lightfoot, W. S., Jaffin, R., \& Kumar, A. (2007). Implant placement with or without simultaneous tooth extraction in patients taking oral bisphosphonates: postoperative healing, early follow-up, and the incidence of complications in two private practices. Journal of periodontology, 78(9), 16641669. https://doi.org/10.1902/jop.2007.060514 
Gelazius, R., Poskevicius, L., Sakavicius, D., Grimuta, V., \& Juodzbalys, G. (2018). Dental Implant Placement in Patients on Bisphosphonate Therapy: a Systematic Review. Journal of oral \& maxillofacial research, 9(3), e2. https://doi.org/10.5037/jomr.2018.9302

Ghidini, G., Manfredi, M., Giovannacci, I., Mergoni, G., Sarraj, A., Mureddu, M., Giunta, G., Bonanini, M., Meleti, M., \& Vescovi, P. (2017). Medicationrelated osteonecrosis of the jaw: risk factors in patients under biphosphonate versus patients under antiresorptive-antiangiogenic drugs. Minerva stomatologica, 66(4), 135-140. https://doi.org/10.23736/S0026-4970.17.04056-0

Giovannacci, I., Meleti, M., Manfredi, M., Mortellaro, C., Greco Lucchina, A., Bonanini, M., \& Vescovi, P. (2016). Medication-Related Osteonecrosis of the Jaw Around Dental Implants: Implant Surgery-Triggered or Implant Presence-Triggered Osteonecrosis? The Journal of craniofacial surgery, 27(3), 697-701. https://doi.org/10.1097/SCS.0000000000002564

Goss, A., Bartold, M., Sambrook, P., \& Hawker, P. (2010). The nature and frequency of bisphosphonate-associated osteonecrosis of the jaws in dental implant patients: a South Australian case series. Journal of oral and maxillofacial surgery: official journal of the American Association of Oral and Maxillofacial Surgeons, 68(2), 337-343. https://doi.org/10.1016/j.joms.2009.09.037

Granate-Marques, A., Polis-Yanes, C., Seminario-Amez, M., Jané-Salas, E., \& López-López, J. (2019). Medication-related osteonecrosis of the jaw associated with implant and regenerative treatments: Systematic review. Medicina oral, patologia oral y cirugia bucal, 24(2), e195-e203. https://doi.org/10.4317/medoral.22691

Grant, B. T., Amenedo, C., Freeman, K., \& Kraut, R. A. (2008). Outcomes of placing dental implants in patients taking oral bisphosphonates: a review of 115 cases. Journal of oral and maxillofacial surgery: official journal of the American Association of Oral and Maxillofacial Surgeons, 66(2), 223-230. https://doi.org/10.1016/j.joms.2007.09.019

Guazzo, R., Sbricoli, L., Ricci, S., Bressan, E., Piattelli, A., \& Iaculli, F. (2017). Medication-Related Osteonecrosis of the Jaw and Dental Implants Failures: A Systematic Review. The Journal of oral implantology, 43(1), 51-57. https://doi.org/10.1563/aaid-joi-16-00057

Ikebe, T. (2013). Pathophysiology of BRONJ: Drug-related osteoclastic disease of the jaw. Oral Science International,10:1-8.

Jacobsen, C., Metzler, P., Rössle, M., Obwegeser, J., Zemann, W., \& Grätz, K. W. (2013). Osteopathology induced by bisphosphonates and dental implants: clinical observations. Clinical oral investigations, 17(1), 167-175. https://doi.org/10.1007/s00784-012-0708-2

Jeffcoat M. K. (2006). Safety of oral bisphosphonates: controlled studies on alveolar bone. The International journal of oral \& maxillofacial implants, 21(3), 349-353.

Kasai, T., Pogrel, M. A., \& Hossaini, M. (2009). The prognosis for dental implants placed in patients taking oral bisphosphonates. Journal of the California Dental Association, 37(1), 39-42.

Kunchur, R., Need, A., Hughes, T., \& Goss, A. (2009). Clinical investigation of C-terminal cross-linking telopeptide test in prevention and management of bisphosphonate-associated osteonecrosis of the jaws. Journal of oral and maxillofacial surgery: official journal of the American Association of Oral and Maxillofacial Surgeons, 67(6), 1167-1173. https://doi.org/10.1016/j.joms.2009.02.004

López-Cedrún, J. L., Sanromán, J. F., García, A., Peñarrocha, M., Feijoo, J. F., Limeres, J., \& Diz, P. (2013). Oral bisphosphonate-related osteonecrosis of the jaws in dental implant patients: a case series. The British journal of oral \& maxillofacial surgery, 51(8), 874-879. https://doi.org/10.1016/j.bjoms.2013.06.011

Marx R. E. (2003). Pamidronate (Aredia) and zoledronate (Zometa) induced avascular necrosis of the jaws: a growing epidemic. Journal of oral and maxillofacial surgery: official journal of the American Association of Oral and Maxillofacial Surgeons, 61(9), 1115-1117. https://doi.org/10.1016/s02782391(03)00720-1

Mücke, T., Krestan, C. R., Mitchell, D. A., Kirschke, J. S., \& Wutzl, A. (2016). Bisphosphonate and Medication-Related Osteonecrosis of the Jaw: A Review. Seminars in musculoskeletal radiology, 20(3), 305-314. https://doi.org/10.1055/s-0036-1592367

Nisi, M., Izzetti, R., Gennai, S., Bellini, P., Graziani, F., \& Gabriele, M. (2020). Surgical Management of Medication-Related Osteonecrosis of the Jaw Patients Related to Dental Implants. The Journal of craniofacial surgery, 31(4), 1037-1041. https://doi.org/10.1097/SCS.0000000000006283

Pichardo, S., van der Hee, J. G., Fiocco, M., Appelman-Dijkstra, N. M., \& van Merkesteyn, J. (2020). Dental implants as risk factors for patients with medication-related osteonecrosis of the jaws (MRONJ). The British journal of oral \& maxillofacial surgery, 58(7), 771-776. https://doi.org/10.1016/j.bjoms.2020.03.022

Rawal, S. Y., \& Hilal, G. (2020). Osteonecrosis and spontaneous exfoliation of dental implants associated with oral bisphosphonate therapy: a case report. Aust Dent J, 65(1):100-103. doi:10.1111/adj.12738

Rodan, G. A., \& Reszka, A. A. (2002). Bisphosphonate mechanism of action. Curr Mol Med, 2(6):571-577. 10.2174/1566524023362104

Ruggiero, S. L., Dodson, T. B., Fantasia, J., Goodday, R., Aghaloo, T., Mehrotra, B., O'Ryan, F., \& American Association of Oral and Maxillofacial Surgeons. (2014). American Association of Oral and Maxillofacial Surgeons position paper on medication-related osteonecrosis of the jaw--2014 update. Journal of oral and maxillofacial surgery: official journal of the American Association of Oral and Maxillofacial Surgeons, 72(10), 1938-1956. https://doi.org/10.1016/j.joms.2014.04.031

Ruggiero, S. L., Dodson, T. B., Assael, L. A., Landesberg, R., Marx, R. É., \& Mehrotra, B. (2009). American Association of Oral and Maxillofacial Surgeons. Artigo de posição da Associação Americana de Cirurgiões Bucais e Maxilofaciais sobre osteonecrose da mandíbula relacionada a bifosfonatos - atualização de 2009. J Oral Maxillofac Surg, 67: 2-12.

Shibahara T. (2019). Antiresorptive Agent-Related Osteonecrosis of the Jaw (ARONJ): A Twist of Fate in the Bone. The Tohoku journal of experimental medicine, 247(2), 75-86. https://doi.org/10.1620/tjem.247.75

Stavropoulos, A., Bertl, K., Pietschmann, P., Pandis, N., Schiødt, M., \& Klinge, B. (2018). The effect of antiresorptive drugs on implant therapy: Systematic review and meta-analysis. Clinical oral implants research, 29 Suppl 18, 54-92. https://doi.org/10.1111/clr.13282 
Research, Society and Development, v. 10, n. 13, e211101321074, 2021

(CC BY 4.0) | ISSN 2525-3409 | DOI: http://dx.doi.org/10.33448/rsd-v10i13.21074

Stockmann, P., Nkenke, E., Englbrecht, M., Schlittenbauer, T., Wehrhan, F., Rauh, C., Beckmann, M. W., Fasching, P. A., Kreusch, T., Mackensen, A., Wullich, B., Schett, G., \& Spriewald, B. M. (2013). Major histocompatibility complex class II polymorphisms are associated with the development of antiresorptive agent-induced osteonecrosis of the jaw. Journal of cranio-maxillo-facial surgery: official publication of the European Association for CranioMaxillo-Facial Surgery, 41(1), 71-75. https://doi.org/10.1016/j.jcms.2012.10.018

Tam, Y., Kar, K., Nowzari, H., Cha, H. S., \& Ahn, K. M. (2014). Osteonecrosis of the jaw after implant surgery in patients treated with bisphosphonates--a presentation of six consecutive cases. Clinical implant dentistry and related research, 16(5), 751-761. https://doi.org/10.1111/cid.12048

Vescovi P. (2012). Bisphosphonates and osteonecrosis: an open matter. Clinical cases in mineral and bone metabolism : the official journal of the Italian Society of Osteoporosis, Mineral Metabolism, and Skeletal Diseases, 9(3), 142-144.

Vescovi, P., Merigo, E., Meleti, M., Manfredi, M., Guidotti, R., \& Nammour, S. (2012). Bisphosphonates-related osteonecrosis of the jaws: a concise review of the literature and a report of a single-centre experience with 151 patients. Journal of oral pathology \& medicine : official publication of the International Association of Oral Pathologists and the American Academy of Oral Pathology, 41(3), 214-221. https://doi.org/10.1111/j.1600-0714.2011.01091.x

Yip, J. K., Borrell, L. N., Cho, S. C., Francisco, H., \& Tarnow, D. P. (2012). Association between oral bisphosphonate use and dental implant failure among middle-aged women. Journal of clinical periodontology, 39(4), 408-414. https://doi.org/10.1111/j.1600-051X.2012.01854.X 